\title{
酸化ルテニウム担持カーボン電極擬似電気化学キャパシタ
}

\author{
岩田＼cjkstart友夫 ${ }^{\mathrm{a}, *}$, 広瀬 隆之, 植田厚, 佐渡 直彦
}

(株) 富士電機総合研究所 (厂240-0194 横須賀市長坂 2-2-1)

a 現在：富士電機 (株)（テ141-0032 東京都品川区大崎 1-11-2）

\section{Ruthenium Oxide Impregnated Carbon Pseudocapacitors}

\author{
Tomoo IWATA, ${ }^{\mathrm{a}, *}$ Takayuki HIROSE, Atushi UEDA, and Naoahiko SAWTARI
}

Fuji Electric Corporate Research and Development, Ltd. (2-2-1 Nagasaka, Yokosuka-City, Kanagawa 240-0194, Japan) aPresent address: Fuji Electric Co., Ltd. (11-2, Osaki 1-chome, Shinagawa-ku, Tokyo 141-0032, Japan)

Received June 14, 2000 ; Accepted November 21, 2000

\begin{abstract}
$\mathrm{RuO}_{2}$-impregnated carbon electrodes for an electrochemical capacitor were prepared by the direct impregnation of $\mathrm{RuO}_{2}$ on carbon with the alkaline neutralization in the $\mathrm{RuCl}_{3}$ aqueous solution, and have a high specific capacitance $\left(180 \mathrm{Fg}^{-1}\right.$ for $\left.11.0 \mathrm{wt} \% \mathrm{RuO}_{2} / \mathrm{C}\right) . \mathrm{RuO}_{2}$ particles on the carbon are 2 or $3 \mathrm{~nm}$ in diameter, and their structure was amorphous even after annealing at $573 \mathrm{~K}$. The specific pseudocapacitances per $\mathrm{RuO}_{2}$ of the $1.45,5.03$ and $11.0 \mathrm{wt} \%$ $\mathrm{RuO}_{2}$-impregnated carbon electrodes were 1079,1055 and $785 \mathrm{Fg}^{-1} \mathrm{RuO}_{2}$, respectively. They were twice and more as high as calculated value on the basis of a model of hydrogen adsorption on the surface ruthenium and oxygen. This suggests that hydrogen not only adsorbs on the surface but also intercalates into the inner lattice sites of ruthenium and oxygen due to the ultra-fine and amorphous structure of $\mathrm{RuO}_{2}$ particles on the carbon.
\end{abstract}

Key Words : $\mathrm{RuO}_{2}$, Carbon, Impreganation, Pseudocapacitor

\section{1 緒 言}

電気二重層キャパシタは,これまで IC/LSI 回路, 玩具, 時計, カメラなどに用いられ, 近年, 電気自動車やハイブリ ッド自動車あるいは燃料電池自動車の補助電源に用いられよ うとしている1，2).一方，擬似二重層容量を原理とする擬似 電気化学キャパシタも, 最近, それらの用途を目指した研究 開発が盛んとなっている.

擬似電気化学キャパシタはこれまで酸化ルテニウムを用い た研究が多い. Hepel らは単結晶酸化ルテニウムの結晶面と 水素イオンの配向性の関係を報告している ${ }^{3)}$. またTrasatti らは擬似二重層容量と電気二重層容量との詳細な比較を検討 している4). 一方, Conway は擬似電気化学キャパシタの電 極材料として酸化ルテニウムを提案している5). そして Zheng らはゾルゲル法で酸化ルテニウムを調製し，単位重 量当たり $720 \mathrm{Fg}^{-1}$ の擬似二重層容量を得ている6.7)。また 高須らは酸化バナジウムを化合した酸化ルテニウムで高い擬 似二重層容量を得ている ${ }^{8)}$.

酸化ルテニウムの擬似二重層容量は水素イオンが酸化ルテ ニウム表面に吸着することにより生じる.これより, 酸化ル テニウム単位重量当たりの擬似二重層容量は酸化ルテニウム の比表面積に比例することが考えられ，単位重量当たりの擬 似二重層容量の増大には酸化ルテニウムの比表面皘の増大が 重要となり, 比表面積を増大するには酸化ルテニウムの微粒 子化が鍵となる. Zheng らは低温ゾルゲル法により酸化ル テニウムの微粒子化を図っており ${ }^{6,7)}$, 高須らは酸化バナジ ウムの化合で酸化ルテニウムを微粒子化して ${ }^{8)}$, いずれも前
述の高い擬似二重層容量を得ているのである。このように酸 化ルテニウム単位重量当たりの擬似二重層容量の増大には酸 化ルテニウムの微粒子化が重要となる.

一方, Zheng らはまた, アルカリ中和法であらかじめ酸 化ルテニウム粉末を作製しこれにカーボンブラック粉末を混 合して電気化学キャパシタの電極を作製している.これはカ 一ボンブラックを添加して電極の空孔率を増加し, 電解液中 のイオン移動抵抗を隇少させているのである。その結果, 彼 らは酸化ルテニウム重量当たり $10 \mathrm{kWkg}^{-1}$ の高出力密度を 得ている ${ }^{9)}$.

ところで, 酸化ルテニウムの価格は $1 \mathrm{~g}$ 当たり 100 円から 200 冈であり, カーボンの 1 円ないし 2 円と比較して高価で ある、このため酸化ルテニウムを電気化学キャパシタの電極 材料に用いるには，できるだけ酸化ルテニウムの使用量を少 なくすることが工業的に重要となる.

そこで酸化ルテニウムをカーボンに担持することが極めて 重要となる. 何故なら酸化ルテニウムをカーボンに担持する と, 酸化ルテニウムが超微粒子化されてカーボンに担持され るためその広大な比表面積で高擬似二重層容量が期待され, また高空孔率のカーボンマトリックスによりイオン移動抵抗 の減少で電極内部抵抗の低隇が期待でき，しかも電極コスト の低価格が期待されるからである.

Miller らは CVD 法によりナノサイズの酸化ルテニウム超 微粒子をカーボンに形成して $206 \mathrm{Fg}^{-1}$ の擬似二重層容量を 得ている.また, Lin らはカーボンに酸化ルテニウムのキセ ロゲルを形成して $256 \mathrm{Fg}^{-1}$ の擬似二重層容量を得て, しか 
もサイクリックボルタモグラムで 2000 回以上の充放電を達 成している11).

このように酸化ルテニウムをカーボンに担持する方法は, 電気化学キャパシタの開発にとって重要であり, 製法の簡便 さも求められる.そこで本報では工業的な観点，すなわち性 能とコストと製法に鑑み、アルカリ中和法でカーボンに直接 酸化ルテニウムを担持する方法をあらたに開発し，それによ って得られた酸化ルテニウム担持カーボン電極の擬似電気化 学キャパシ夕特性について述べる。

\section{2 実 験}

酸化ルテニウムの出発原料には徳力製の $\mathrm{RuCl}_{3} \cdot 3 \mathrm{H}_{2} \mathrm{O}$ を 用い, カーボンにはキャボット社の Vulcan-XC72R と Black Pearls-2000の 2 種類を用いた。これらのカーボンはあらか じめ窒素ガスにより BET 比表面積を測定した。

酸化ルテニウム担持カーボン電極は次のようにして作製し た。

所定量の Vulcan-XC72 カ ロケミカル社のテフロン分散溶液と混合し，これを十分に攪 拌混練して，高粘性を有するペーストが作製された。次にこ れをカレンダーロール法によりカーボンシートに成形し，真 空乾燥して，テフロン含有カーボンシトートを得た。こうし て得られたカーボンシートを $0.1 \mathrm{M} の \mathrm{RuCl}_{3} \cdot 3 \mathrm{H}_{2} \mathrm{O}$ 水溶液 に浸漬して，ついで $\mathrm{pH}$ を 7 から 8 に維持しながら $0.1 \mathrm{M}$ の $\mathrm{NaOH}$ 水溶液を少量ずつ添加してカーボン上に酸化ルテニ ウムを形成した。この後，カーボンシートは硝酸銀水溶液に て $\mathrm{Cl}^{-}$が検知できなくなるまで純水で $\mathrm{Na}^{+}$と $\mathrm{Cl}^{-}$を洗い落と した。洗浄後，カーボンシートは窒素ガス雲囲気下， $423 \mathrm{~K}$ で 10 時間加熱乾燥した。こうして得られた酸化ルテニウム 担持 Vulcan-XC72R カーボン電極は厚さが $0.3 \mathrm{~mm}$ から 0.5 $\mathrm{mm}$ であった。なおこの電極の一部はさらに $473 \mathrm{~K}$ なは $573 \mathrm{~K}$ で 1 時間, 加熱乾燥された。

一方, 所定量の Black Pearls-2000 カーボン粉末を $0.1 \mathrm{M}$ の $\mathrm{RuCl}_{3} \cdot 3 \mathrm{H}_{2} \mathrm{O}$ 水溶液に浸漬した後, このカーボン分散溶 液を攪拌しながら，前述と同様に $\mathrm{pH}$ を 7 から8に維持しな がら $0.1 \mathrm{M} の \mathrm{NaOH}$ 水溶液を少量ずつ添加してカーボン上 に酸化ルテニウムを形成した。この後，酸化ルデニウム担持 カーボン分散溶液は滤紙で滤過され，前述のように純水で $\mathrm{Na}^{+}$と $\mathrm{Cl}^{-}$を洗い落とした，得られた酸化ルテニウム担持カ 一ボン粉末は，窒素ガス雲囲気下， $423 \mathrm{~K}$ で 10 時間加熱乾 燥された. 次に乾燥後の酸化ルテニウム担持カーボン粉末の 所定量を所定量のテフロン分散溶液と混合し，これを十分に 攪拌混練してペーストを作製し，カレンダーロール法にてカ 一ボンシートを成形し，これを真空乾燥して，酸化ルテニウ ム担持 Black Pearls-2000 カーボン電極を得た。この電極の 厚さは $0.4 \mathrm{~mm}$ から $0.6 \mathrm{~mm}$ であった。またこの電極の一部 はさらに $573 \mathrm{~K}$ で 1 時間, 加熱乾燥された。

それぞれのカーボンの電気二重層容量を評価するために, 酸化ルテニウムを担持しないカーボンのみの電極も作製した。

ICP（誘導結合高周波プラズマ分光分析）により酸化ルテ ニウム担持カーボン電極の組成を分析した.

カーボンに担持された酸化ルテニウムの結晶性と結晶子の サイズを評価するため，それぞれの酸化ルテニウム担持カー ボン電極の XRD（X 線回折）を測定した.

XPS（X 線光電子分光）分析のために, 酸化ルテニウムを
アモルファスシリコンに担持した。酸化ルテニウムを担持し た試料では, ルテニウムの $3 \mathrm{~d}$ に起因する光電子ピークとカ 一ボン $1 \mathrm{~s}$ に起因する光電子ピークが重なってルテニウムの 価数が分析できない. $0.1 \mathrm{M} の \mathrm{RuCl}_{3} \cdot 3 \mathrm{H}_{2} \mathrm{O}$ 水溶液に 0.1 $\mathrm{M} の \mathrm{NaOH}$ 水溶液を添加して酸化ルテニウムの沈殿を作製 し，デカンテーションによりペーストを作製して，これをア モルファスシリコンウエハーに塗り, 窒素ガス雲囲気下, $423 \mathrm{~K}$ で 10 時間加熱乾燥した。この試料についても XRDを 测定した.

カーボンに担持された酸化ルテニウムのモロホロジーを観 察するため, 酸化ルテニウム担持カーボン電極のTEM（透 過型電子顕微鏡）観察がなされた。

酸化ルテニウム担持カーボン電極の擬似電気容量は次のよ うにして評洒された。

打ち抜きポンチにより直径 $10 \mathrm{~mm}$ の酸化ルテニウム担持 カーボン電極を打ち抜き，これを 2 枚の $10 \mathrm{~mm} \times 10 \mathrm{~mm}$ サ イズの白金ネットで挟んで四角をスポット溶接し，その一端 に白金リード線をスポット溶接して擬似二重層容量测定電極 とした，擬似二重層容量の測定に用いた電解セルは通常の $\mathrm{H}$ 型セルで，電解液には窒素ガスで脱酸素された $0.5 \mathrm{M}$ と 30 $\mathrm{wt} \% \mathrm{H}_{2} \mathrm{SO}_{4}$ 水溶液が用いられた. 参照電極には $\mathrm{Ag} / \mathrm{AgCl}$ 電極を用い, 飽和 $\mathrm{KCl}$ 塩橋でルギンキャピラリーと参照電 極を接続した。電位は $\mathrm{Ag} / \mathrm{AgCl}$ 基準で示した。電極の電気 二重層容量および擬似二重層容量は後述するようにサイクリ ックボルタモグラム法により求めた. すべての测定は液温 $25 \pm 11^{\circ} \mathrm{C}$ で行われた.

\section{3 結果と考察}

Fig. 1にアモルファスシリコンウエハーに担持した酸化ル テニウムのXPS スペクトルを示す. $281.0 \mathrm{eV}$ と $284.9 \mathrm{eV} に$ 示される電子スペクトルピークは, 文献 ${ }^{12)} の \mathrm{RuO}_{2}$ のルテニ ウム $3 \mathrm{~d}_{5 / 2}$ と $3 \mathrm{~d}_{3 / 2}$ のスペクトルピーク位置とそれぞれほぼ一 致した.また $529.4 \mathrm{eV}$ のピークは $\mathrm{RuO}_{2}$ の酸素 $1 \mathrm{~s}$ のスペク トルピーク位置 ${ }^{13)}$ とほほ一致した。これよりカーボンに担持 された酸化ルテニウムは $\mathrm{RuO}_{2}$ と推定された。

Table 1 にそれぞれのカーボンの BET 比表面積と ICP 法 で分析した $\mathrm{RuO}_{2}$ 担持カーボン電極の組成を示す。もし $\mathrm{RuO}_{2}$ の担持量がカーボンの比表面積に比例し, $\mathrm{RuO}_{2}$ の担 持効率がカーボンによらず 100\%であるなら, Vulcan-XC $72^{\mathrm{R}}$ の測定值 $1.45 \mathrm{wt} \%$ 基準にすると, Black Pearls-2000 の $\mathrm{RuO}_{2}$ の 担持量 $W_{\mathrm{RuO}_{2}}$ は Vulcan-XC72 $2^{\mathrm{R}}$ と Black Pearls2000 の BET 比表面積 $219 \mathrm{~m}^{2} \mathrm{~g}^{-1}$ と $1370 \mathrm{~m}^{2} \mathrm{~g}^{-1}$ より

$$
W_{\mathrm{RuO} 2}=\frac{1.45 \times 1370}{219}=9.07
$$

の $9.07 \mathrm{wt} \%$ と計算される. 実测值は $11.0 \mathrm{wt} \%$ むらった。ま た $\mathrm{RuCl}_{3} \cdot 3 \mathrm{H}_{2} \mathrm{O}$ の量を半隇したものでは $5.03 \mathrm{wt} \%$ たっった. このように，アルカリ中和法による酸化ルテニウムの担持は， カーボンの比表面積と $\mathrm{RuCl}_{3} \cdot 3 \mathrm{H}_{2} \mathrm{O}$ の量により制御できる.

Fig. 2 に Black Pearls-2000 カーボン電極の典型的なサイ クリックボルタモグラムを示す. $\mathrm{RuO}_{2}$ の担持量は無担持つ まり $0 \mathrm{wt} \%$ と $11.0 \mathrm{wt} \%$ ある. 電解液は $30 \mathrm{wt} \% \mathrm{H}_{2} \mathrm{SO}_{4}$ 水

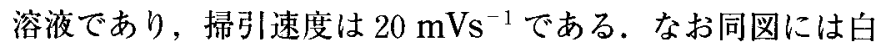
金ネットのみのボルタモグラムは電流值の絶対值が $1 \mathrm{~mA}$ 以

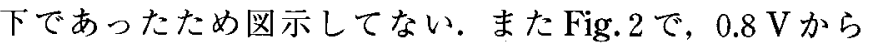



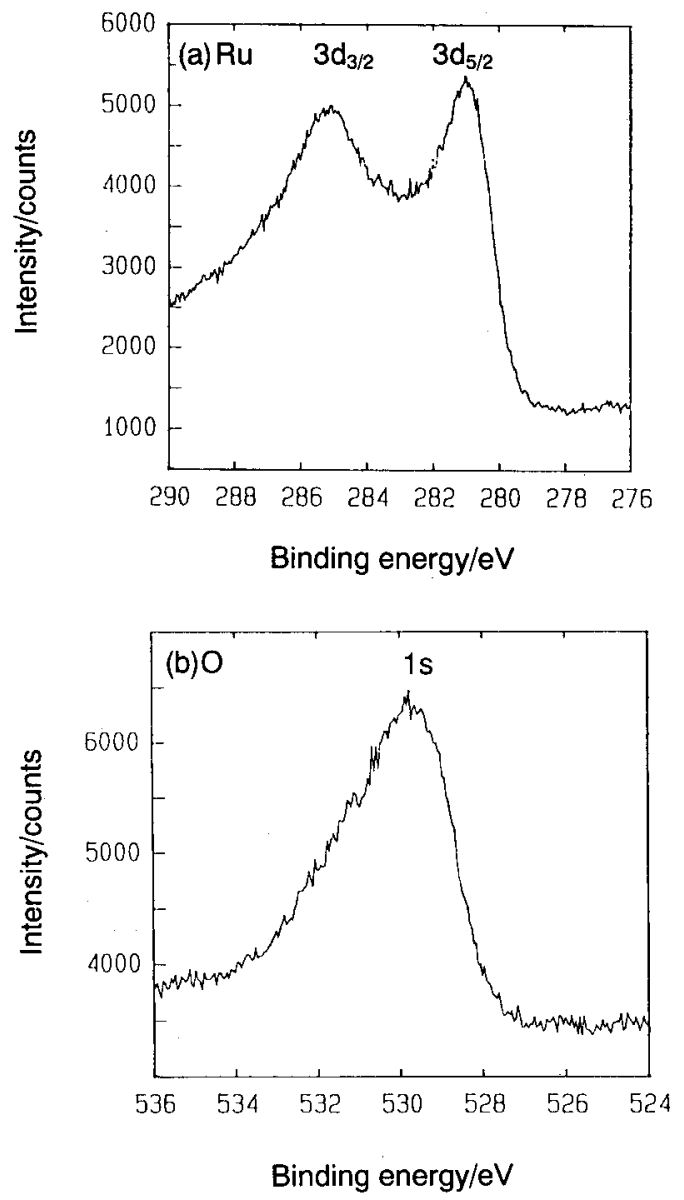

Fig. 1 XPS profiles of ruthenium oxide thin film on amorphous silicon wafer. (a): ruthenium XPS profile, (b): oxygen XPS profile.

$1.1 \mathrm{~V}$ のアノード電流には, $\mathrm{RuO}_{2}$ 近傍のカーボンの酸化電 流も含まれているものと思われる。

一方, $0.5 \mathrm{M} \mathrm{H}_{2} \mathrm{SO}_{4}$ 水溶液電解液での $1.45 \mathrm{wt} \%-\mathrm{RuO}_{2}$ 担 持 Vulcan-XC72R カーボン電極や, $30 \mathrm{wt} \% \mathrm{H}_{2} \mathrm{SO}_{4}$ 水溶液電 解液での $5.03 \mathrm{wt} \%-\mathrm{RuO}_{2}$ 担持 Black Pearls-2000 カーボン電 極のサイクリックボルタムグラムも同様に得られ，また $\mathrm{RuO}_{2}$ 無担持のカーボン電極のサイクリックボルタムグラム も同様に測定されて，それぞれの電気容量を（2）式により 算出した.

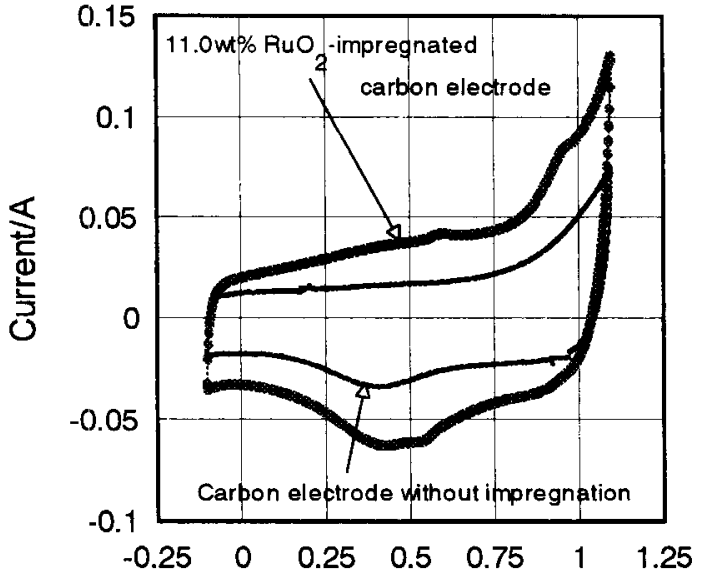

\section{Electrode potential/ $\mathrm{V}$ vs. Ag/AgCl}

Fig. 2 Cyclic voltammogram curves of $11.0 \mathrm{wt} \% \mathrm{RuO}_{2}$ impregnated carbon electrode and carbon electrode without impregnation in $30 \mathrm{wt} \% \mathrm{H}_{2} \mathrm{SO}_{4}$ solution with sweep rate of 20 $\mathrm{mV} \mathrm{s}^{-1}$.

$$
C_{\text {electrode }}=\frac{1}{E_{2}-E_{1}} \int_{E_{1}}^{E_{2}} \frac{I_{\mathrm{a}}}{S_{\mathrm{E}}} d E
$$

ここで $C_{\text {electrode }}$ は電極の電気容量であり， $S_{\mathrm{E}}$ は掃引速度， $I_{\mathrm{a}}$ はアノード電流, $E_{2}-E_{1}$ は掃引電位幅で, $E_{1}$ と $E_{2}$ は参照電

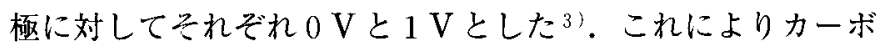
ン電極の電気二重層容量は $\mathrm{RuO}_{2}$ 無担持のカーボン電極の電 気容量により求まり, $\mathrm{RuO}_{2}$ 担持カーボン電極の電気容量か らそれを差し引くことで $\mathrm{RuO}_{2}$ の擬似二重層容量が算出され る.

このようにして求まった電気二重層容量は, Vulcan-XC $72^{\mathrm{R}}$ カーボン電極と Black Pearls-2000 カーボン電極でそれ

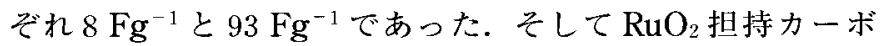
ン電極の $\mathrm{RuO}_{2}$ 単位重量当たりの擬似二重層容量と電極単位 重量当たりの電気容量はTable 2 に示す.

Table 2 より $\mathrm{RuO}_{2}$ 単位重量当たりの擬似二重層容量は $\mathrm{RuO}_{2}$ 担持量が $1.45 \mathrm{wt} \%$ と $5.03 \mathrm{wt} \%$ と $11.0 \mathrm{wt} \%$ それぞれ $1079 \mathrm{Fg}^{-1}$ と $1055 \mathrm{Fg}^{-1}$ と $795 \mathrm{Fg}^{-1}$ であり，これまで報告 されている值 ${ }^{6-11)}$ と同様に大きいことがわかる。またカー

Table 1 Carbon BET area and composition of $\mathrm{RuO}_{2}$-impregnated carbon sheet.

\begin{tabular}{|c|c|c|c|}
\hline No & Carbon & BET area $/ \mathrm{m}^{2} \mathrm{~g}^{-1}$ & Composition/wt $\%$ \\
\hline 1 & Vulcan-XC72 & 219 & $1.45-\mathrm{RuO}_{2} / 32.85-\mathrm{PTFE} / 65.7$-carbon \\
\hline 2 & Black Pearls-2000 & 1370 & $5.03-\mathrm{RuO}_{2} / 14.5-\mathrm{PTFE} / 80.47$-carbon \\
\hline 3 & Black Pearls-2000 & 1370 & $11.0-\mathrm{RuO}_{2} / 14.5-\mathrm{PTFE} / 74.5$-carbon \\
\hline
\end{tabular}

Table 2 Specific pseudocapacitance and specific electrode capacitance.

\begin{tabular}{|c|c|c|c|c|}
\hline No & Carbon & $\begin{array}{c}\mathrm{RuO}_{2} \\
\text { content } \\
/ \mathrm{Wt} \%\end{array}$ & $\begin{array}{c}\mathrm{RuO}_{2} \\
\text { pseudocapacitance } \\
/ \mathrm{Fg}^{-1}\end{array}$ & $\begin{array}{c}\mathrm{RuO}_{2} \text { impregnated carbon } \\
\text { electrode capacitance } \\
/ \mathrm{Fg}^{-1}\end{array}$ \\
\hline 1 & Vulcan-XC $72^{\mathrm{R}}$ & 1.45 & 1079 & 18.5 \\
\hline 2 & Black Pearls-2000 & 5.03 & 1055 & 152.9 \\
\hline 3 & Black Pearls-2000 & 11.0 & 795 & 179.8 \\
\hline
\end{tabular}




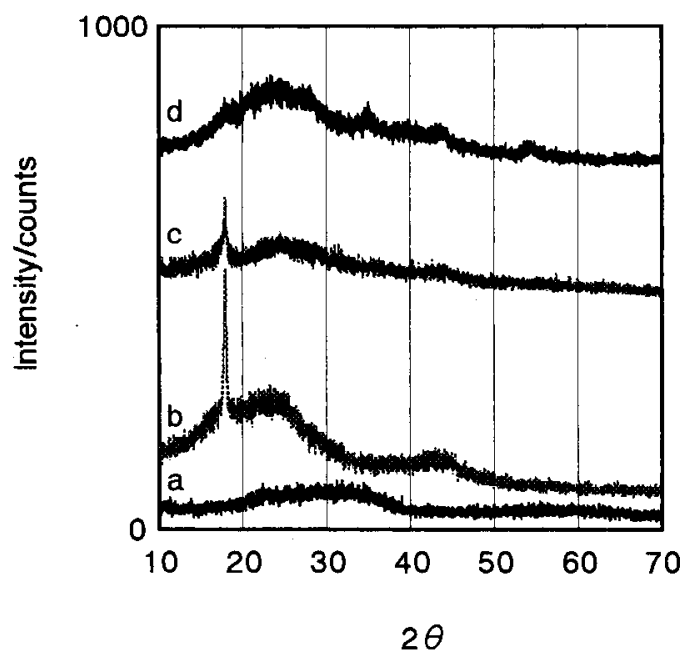

Fig. $3 \mathrm{XRD}$ profiles. a: $\mathrm{RuO}_{2}$ thin film on amorphous silicon, b: carbon sheet without impregnation dried at $423 \mathrm{~K}$, c: 11.0 wt $\% \mathrm{RuO}_{2}$-impregnated carbon sheet dried at $423 \mathrm{~K}$, d: 11.0 $\mathrm{wt} \% \mathrm{RuO}_{2}$-impregnated carbon sheet additionally annealed at $573 \mathrm{~K}$.

ボン担体が Black Pearls-2000 では, $\mathrm{RuO}_{2}$ 単位重量当たり の擬似二重層容量は $\mathrm{RuO}_{2}$ の担持量とともに減少し, $\mathrm{RuO}_{2}$ 担持量が $11.0 \mathrm{wt} \%$ ば電極単位重量当たりの電気容量は $180 \mathrm{Fg}^{-1}$ となる.

Fig. 3 にスムージング処理なしの XRD スペクトルを示す. アモルファスシリコンウエハーに担持された $\mathrm{RuO}_{2}$ は，アモ ルファスであることがわかる. $423 \mathrm{~K}$ で加熱乾燥した $\mathrm{RuO}_{2}$ 無担持のカーボン電極の $2 \theta$ が $18^{\circ}$ のピークは，バインダ 一材であるテフロンによるものである. $423 \mathrm{~K}$ で加熱乾燥し た $11.0 \mathrm{wt} \%-\mathrm{RuO}_{2}$ 担持カーボン電極の $\mathrm{XRD}$ スペクトルは $\mathrm{RuO}_{2}$ 無担持の場合とほぼ同じであった. $573 \mathrm{~K} て ゙$ 加熱アニ ールした電極では，テフロンによるピークが消失し，2 $\theta$ が $28^{\circ} ， 35^{\circ} ， 55^{\circ}$ にそれぞれ $\mathrm{RuO}_{2}$ の (110)，(101)，(211) に帰属するピーク7がわずかに認められたテテフロンピーク の消失は，テフロンが熱分解したことによるものと推察され る.一方，図示はしていないが, $1.45 \mathrm{wt} \%-\mathrm{RuO}_{2}$ 担持カーボ ン電極では, $573 \mathrm{~K}$ で加熱アニールしても $\mathrm{RuO}_{2}$ に帰属する ピークはまったく認められなかった。

Zhengらは本報と同様にアルカリ中和法によりカーボン 担持なしで $\mathrm{RuO}_{2}$ を作製して，加熱アニール温度 $423 \mathrm{~K}$ 以下 では $\mathrm{RuO}_{2}$ に帰属するXRD ピークを観測していないが，448 $\mathrm{K}$ 以上では $\mathrm{RuO}_{2}$ に帰属するピークを観測している7). 以上 のことからカーボンに担持された $\mathrm{RuO}_{2}$ はアモルファスの超 微粒子であり，かつその $\mathrm{RuO}_{2}$ 超微粒子はカーボンに担持さ れることにより焼結が抑制されるものと推察され，これが $\mathrm{RuO}_{2}$ のカーボン担持効果であると考えられる.

Fig. 4 に $1.45 \mathrm{wt} \%-\mathrm{RuO}_{2}$ 担持カーボン電極の典型的な TEM 写真を示す. $\mathrm{RuO}_{2}$ 担持量は $1.45 \mathrm{wt} \%$ ある. XRD で予想されたようにカーボンに担持された $\mathrm{RuO}_{2}$ は超微粒子 化していることがわかる. $\mathrm{RuO}_{2}$ の担持量が $5.03 \mathrm{wt} \%$ と 11.0 $\mathrm{wt} \%$ のカーボン電極でも同様に超微粒子化が認められ, $\mathrm{RuO}_{2}$ の担持量が $1.45 \mathrm{wt} \%$ と $5.03 \mathrm{wt} \%$ ではそれらの一次粒 子径は $2 \mathrm{~nm}$ で $11.0 \mathrm{wt} \%$ は $3 \mathrm{~nm}$ であり, $\mathrm{RuO}_{2}$ の粒子径 は担持量とともに增大する。

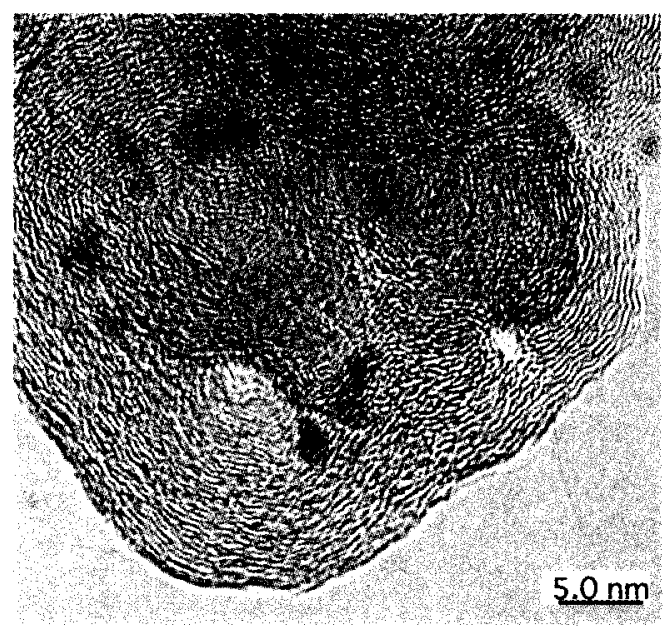

Fig. 4 TEM picture of $1.45 \mathrm{wt} \% \mathrm{RuO}_{2}$-impregnated carbon sheet.

Hepel らは $\mathrm{RuO}_{2}$ の結晶面と水素イオンの吸着配向性につい て議論している ${ }^{3)}$. サイクリックボルタモグラムによって評 価されるカーボンに担持された $\mathrm{RuO}_{2}$ の擬似二重層容量は $\mathrm{RuO}_{2}$ の粒子径に依存し, その関係は（3）式で与えられる.

$$
C=\frac{6}{\rho d} \frac{q}{E_{2}-E_{1}}
$$

ここで $\rho$ は $\mathrm{RuO}_{2}$ の密度であり, $d$ は $\mathrm{RuO}_{2}$ 粒子径で, $E_{2}$ $-E_{1}$ は前述の掃引電位幅で， $q$ は次の（4）式で与えられる.

$$
q=q_{0} \frac{\sum m_{\mathrm{ijk}} n_{\mathrm{jjk}}}{\sum n_{\mathrm{ijk}}}
$$

ここで $q_{0}$ は素電荷であり, $m_{\mathrm{ijk}}$ は $\mathrm{RuO}_{2}$ 単結晶の結晶面 (ijk) での単位面積当たりのルテニウムと酸素のサイト数で あり, $n_{\mathrm{ijk}}$ は $\mathrm{RuO}_{2}$ 単結晶の単位ユニット中における結晶面 (ijk) の数である. Table 3 に結晶面 $(i j k)$ の $m_{\mathrm{ijk}}$ と $n_{\mathrm{ijk}}$ を 示す.なおここで $\mathrm{RuO}_{2}$ 単結晶形はルチル形としている.

Table 3 の $m_{\mathrm{ijk}}$ と $n_{\mathrm{ijk}}$ を用い，(4) 式より $q$ を算出すると $167 \mu \mathrm{C} \mathrm{cm}^{-2}$ と求まる. Fig. 5 に $\mathrm{RuO}_{2}$ の粒子径と $\mathrm{RuO}_{2}$ の 擬似二重層容量の関係を示す. 実線は水素イオンがルテニウ ムサイトと酸素サイトに吸着するものと仮定して（3）式と （4）式により算出したものであり，丸印は実測值である. 実 測値の擬似電気容量は計算值の䄪 2 倍となり, これより水素

Table 3 Face $(i j k), m_{\mathrm{ijk}}$ and $n_{\mathrm{jjk}}$ of $\mathrm{RuO}_{2}$.

\begin{tabular}{|c|c|c|c|}
\hline \multirow{2}{*}{ face $(i j k)$} & \multicolumn{2}{|c|}{$m_{\mathrm{ijk}} / \mathrm{cm}^{-2}$} & \multirow{2}{*}{$n_{\mathrm{ijk}}$} \\
\cline { 2 - 3 } & $\mathrm{Ru}$ & $\mathrm{O}$ & 4 \\
\hline$(100)$ & $7.17 \times 10^{14}$ & - & 2 \\
\hline$(001)$ & $4.96 \times 10^{14}$ & $9.92 \times 10^{14}$ & 1 \\
\hline$(110)$ & $10.1 \times 10^{14}$ & $10.1 \times 10^{14}$ & 1 \\
\hline$(110)$ & $10.1 \times 10^{14}$ & $10.1 \times 10^{14}$ & 4 \\
\hline$(\mathbf{1 0 1})$ & $8.16 \times 10^{14}$ & - & 4 \\
\hline$\left(\frac{\mathbf{1}}{2} 01\right)$ & $7.17 \times 10^{14}$ & - & 1 \\
\hline$\left(00 \frac{1}{2}\right)$ & $4.96 \times 10^{14}$ & $9.92 \times 10^{14}$ & 8 \\
\hline$(111)$ & $10.6 \times 10^{14}$ & - & \multirow{2}{*}{} \\
\hline
\end{tabular}



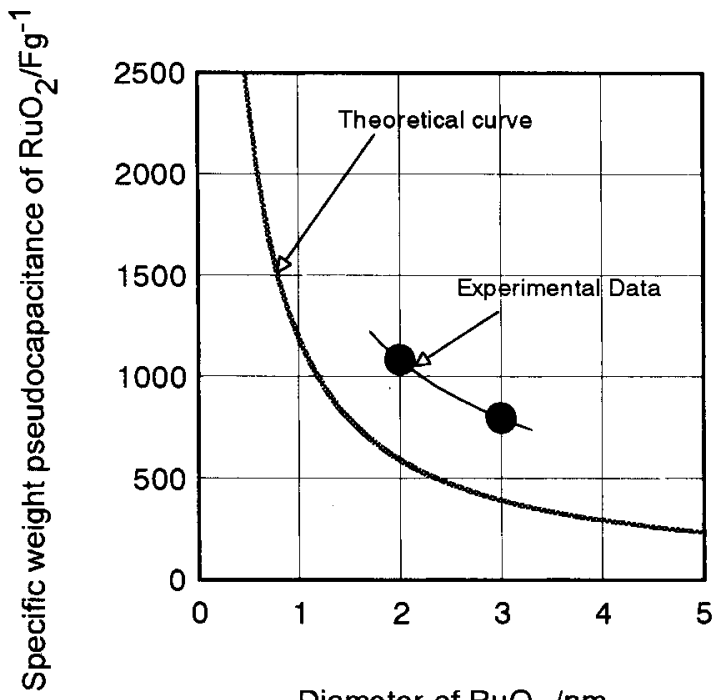

Diameter of $\mathrm{RuO}_{2} / \mathrm{nm}$

Fig. 5 Relationship between diameter of impregnated $\mathrm{RuO}_{2}$ on carbon and specific pseudocapacitance of $\mathrm{RuO}_{2}$ impregnated carbon. Solid line: theoretical specific pseudocapacitance, Closed circle: experimental data.

イオンは粒子の表面に吸着するのみならず粒子内にもインタ 一カレートしているものと推察される.そしてこれは $\mathrm{RuO}_{2}$ をカーボンに担持したことによるものであり， $\mathrm{RuO}_{2}$ のカー ボン担持は $\mathrm{RuO}_{2}$ の超微粒子化をもたらし，これにより前述 の $\mathrm{RuO}_{2}$ 粒子焼結防止効果のみならず，水素イオンのイン夕 一カレーションによる擬似二重層容量の増大効果が生じるこ とになる.

\section{4 結 論}

アルカリ中和法により $\mathrm{RuO}_{2}$ をカーボンに直接担持した $1.45,5.03,11.0 \mathrm{wt} \%-\mathrm{RuO}_{2}$ 担持カーボン電極の $\mathrm{RuO}_{2}$ 単位 重量当たりの擬似二重層気容量は, サイクリックボルタモグ

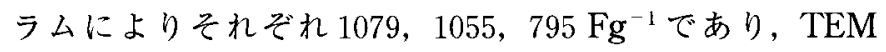
観察により $\mathrm{RuO}_{2}$ の粒子径は $2 \sim 3 \mathrm{~nm}$ であることがわかっ
た。 また XRDにより，カーボンに担持された $\mathrm{RuO}_{2}$ 超微粒 子は, $573 \mathrm{~K}$ の加熱アニールでもほとんど焼結しないことが わかった. さらにサイクリックボルタモグラムより水素イオ ンは $\mathrm{RuO}_{2}$ 粒子の表面に吸着子るのみならず， $\mathrm{RuO}_{2}$ 粒子内 にもインターカレートする ${ }^{3,6,7}$ ことが示唆され，それが $\mathrm{RuO}_{2}$ 単位重量当たりの擬似二重層容量を增大する要因であ ることが推察された。このようにアルカリ中和法による $\mathrm{RuO}_{2}$ の直接カーボン担持は, $\mathrm{RuO}_{2}$ 粒子の焼結防止と擬似 …重層容量の增大に有効であるものと考えられる。な拉 11.0 $\mathrm{wt} \%-\mathrm{RuO}_{2}$ 担持カーボン電極の電極単位重量当たりの電気容 量は $180 \mathrm{Fg}^{-1}$ であった。

\section{文 献}

1) A. F. Burke, in 12th International Electric Vehicle Symposium, p.27 (1995).

2) R. A. Sutula, K. L. Heintner, S. A. Rogers, T. Q. Duong, P. G. Patil, and S. R. Venkateswaran, in 15th International Electric Vehicle Symposium, CD-ROM (1998).

3) T. Hepel, F. H. Pollak, and W. E. O'Grady, J. Electrochem. Soc., 131, 2094 (1984).

4) B. S. Trasatti and P. Kurzweil, Platinum Metals Rev., 38, 46 (1994).

5) B. E. Conway, J. Electrochem. Soc., 138, 1539 (1991).

6) J. P. Zheng, P. J. Cygan, and T. R. Jow, J. Electrochem. Soc., 142, 2699 (1995).

7) J. P. Zheng and T. R. Jow, J. Electrochem. Soc., 142, L6 (1995).

8) Y. Takasu, T. Nakamura, H. Ohkawauchi, and Y. Murakani, J. Electrochem. Soc., 144, 2601 (1997).

9) J. P. Zheng and T. R. Jow, J. Power Sources, 62, 155 (1996).

10) K. M. Miller, B. Dunn, T. D. Tran, and R. W. Pekala, J. Electrochem. Soc., 144, L309 (1997).

11) C. Lin, J. A. Ritter, and B. N. Popov, J. Electrochem. Soc., 146, 3155 (1999).

12) K. S. Kirn and N. Winograd, J. Catal., 35, 66 (1974).

13) K. S. Kirn, W. E. Baitinger, J. W. Amy, and N. Winograd, J. Elect. Spectors., 5, 351 (1974). 